九州大学学術情報リポジトリ

Kyushu University Institutional Repository

\title{
Actual Water Consumption and Water Management in Pddy Field : Referring to the Thai land Gravity Irrigation District (2)
}

Fukuda, Tetsuro

Faculty of Agriculture, Gradute School, Kyushu University

https://doi.org/10.5109/4696

出版情報：九州大学大学院農学研究院紀要. 50 (2)，pp.883-888，2005-10-01. Faculty of Agriculture, Kyushu University

バージョン：

権利関係 : 


\title{
Actual Water Consumption and Water Management in Paddy Field -Referring to the Thailand Gravity Irrigation District (2)-
}

\author{
Tetsuro FUKUDA*
}

\author{
Laboratory of Irrigation and Water Utilization, Division of Regional Environment Science, \\ Department of Bioproduction Environmental Sciences, Faculty of Agriculture, \\ Graduate School, Kyushu University, Fukuoka 812-8581, Japan \\ (Received July 13, 2005 and accepted July 26, 2005)
}

\begin{abstract}
In the Thailand gravity irrigation district, we surveyed consumptive water use and water management actual condition of the paddy field. It is anticipated that the water management of farm land consolidation district and non farm land consolidation district differs. Therefore, the survey was carried out in both districts.

To begin with, 20 plots was respectively selected in each district, and stake for the water level measurement was installed. The water level was measured in a day one time fixed time.

Consumptive water use in a day is obtained as a water level difference in continued two days without inflow and runoff. As a result of the measurement, it was $11 \mathrm{~mm} / \mathrm{d}$ regardless of the degree of farm land consolidation throughout one year. And, operating ponding depth was about $80 \mathrm{~mm}$, and the highest ponding depth was about $150 \mathrm{~mm}$. These results become the data which is very precious for future water demand calculation.
\end{abstract}

\section{INTRODUCTION}

In the previous report, paddy field irrigation water estimation model in the Thailand gravity irrigation district was developed. In the time, it was proven that some dimensions were uncertain. In short, it is necessary to clarify paddy field percolation, operating ponding depth and the highest ponding depth. In the material of Thailand, the example of measuring these in the field is not found. Then, these should be clarified by the observation.

\section{FIELD STUDY}

Consumptive water use in the paddy field is the sum of evapotranspiration and percolation. It is anticipated that percolation (especially, seepage) differs by improvement and controlled state and water management method of the paddy field. Then, measurement on consumptive water use and ponding depth should be carried out in farm land consolidation district (Zone 10) and non farm land consolidation district (Zone 21). The outline of the measurement area is shown in Fig. 1 and Fig. 2. The measurement was carried out in each zone in 20 paddy fields, as it is shown by these figures.

The measuring method: $10 \mathrm{~cm}$ square stakes were pulled in the paddy fields, as it is shown in Fig. 3. The distance $\left(h_{i}\right)$ between water surface and mark on the stake is measured every day in the fixed time. At the same time, the condition of inlet and outlet of the paddy field is also checked.

\footnotetext{
* Corresponding author (E-mail: tfukuda@bpes.kyushu-u.ac.jp)
} 


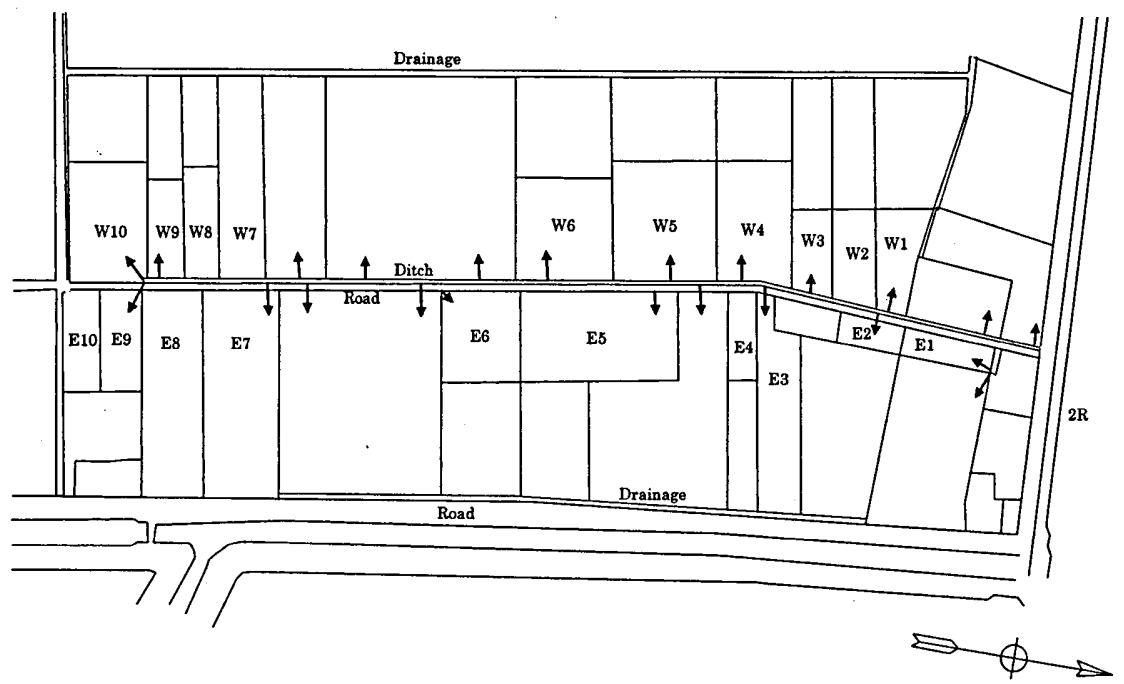

Fig. 1. Layout of Survey Area (Zone 10)

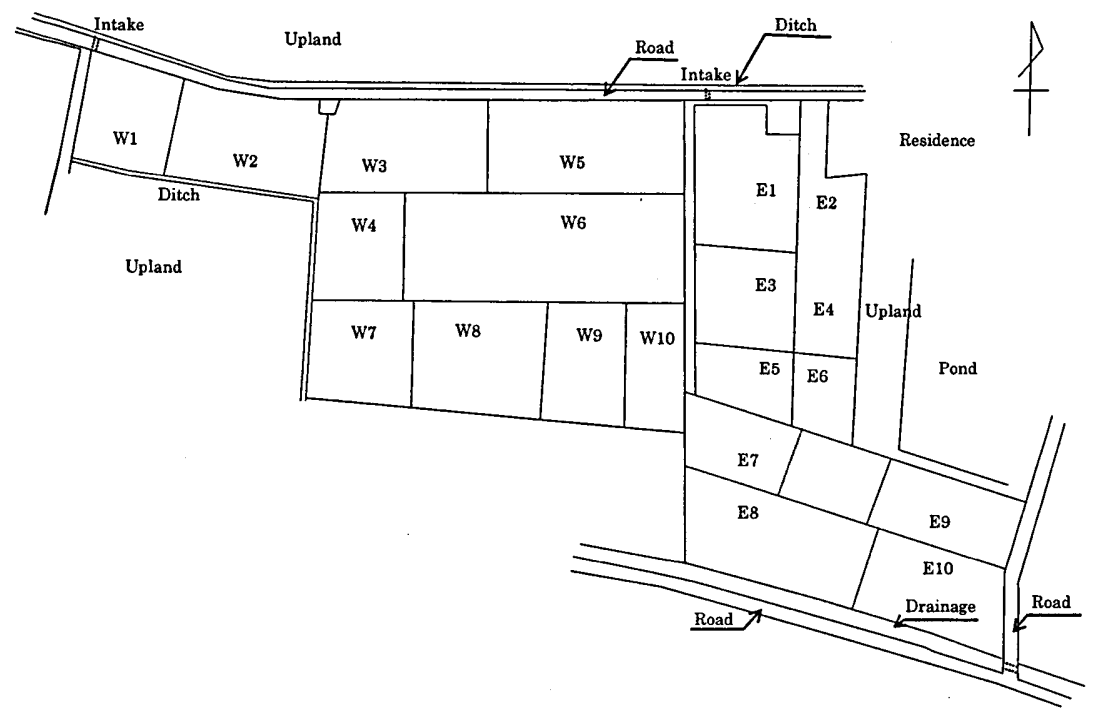

Fig. 2. Layout of Survey Area (Zone 21) 


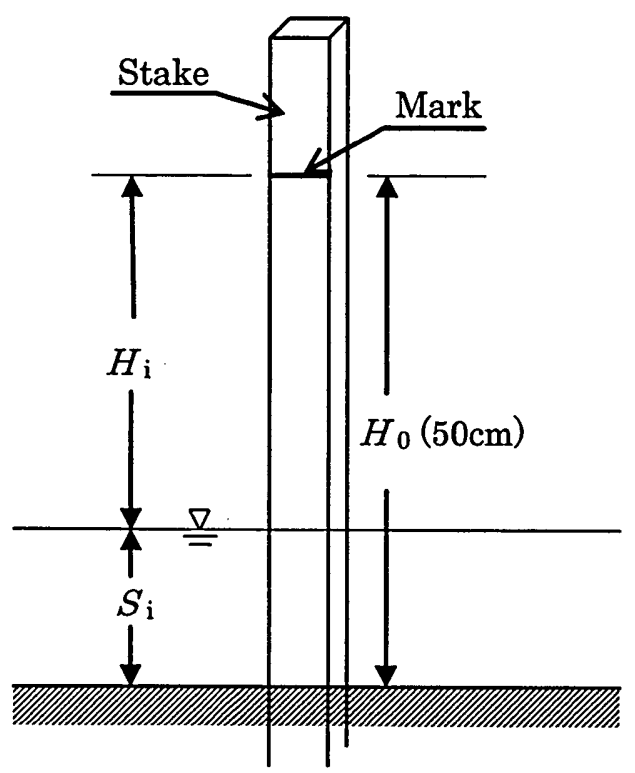

Fig. 3. The Water level measuring method

Ponding depth: Ponding depth $\left(S_{\mathrm{i}}\right)$ is calculated from the difference in distance $\left(H_{0}\right)$ and distance $\left(H_{\mathrm{i}}\right) . H_{0}$ means the distance between paddy field surface and mark on the stake. That is to say, $S_{\mathrm{i}}=H_{0}-H_{\mathrm{i}}$.

Consumptive water use : Consumptive water use $\left(G_{\mathrm{i}}\right)$ in a day in the paddy field is obtained from the difference in ponding depth in continued 2 days. That is to say, $G_{\mathrm{i}}=$ $S_{\mathrm{i}}-S_{\mathrm{i}-1}$. In Japan, consumptive water use in the paddy field is called "Gensuishin". "Gensuishin" means "decrease water depth".

\section{RESULT}

\section{Consumptive water use (Gensuishin)}

The measurement result is shown in Table 1 and Fig. 4.

According to Table 1 and Fig. 4, consumptive water use is average $11.0 \mathrm{~mm} / \mathrm{d}$ in both of farm land consolidation district (Zone 10) and non farm land consolidation district (Zone 21), and this value is constant during the measurement period almost. The examination is tried by the separation of consumptive water use in evapotranspiration and percolation. Though evapotranspiration is around $10 \mathrm{~mm} / \mathrm{d}$ in the middle of growing season, it gradually decreases since then, and in a growing season advanced stage, it becomes about $7 \mathrm{~mm} / \mathrm{d}$. On the other hand, though percolation is 0 in the middle of growing season almost, it gradually increases in the growing season latter half, and it is largest, and it becomes about $6 \mathrm{~mm} / \mathrm{d}$. Still, evapotranspiration is a calculated value which calculated $E T$ ratio $(E T / E)$ by multiplying in potential evaporation by Penman method, and it is not a 
Table 1. Consumptive water use(G), evapotranspiration(ET) and percoration(P)

(Unit : $\mathrm{mm} / \mathrm{d}$ )

\begin{tabular}{|c|c|c|c|c|c|c|c|}
\hline \multirow{2}{*}{ Week } & \multirow{2}{*}{$\mathrm{ET} / \mathrm{E}^{*}$} & \multicolumn{3}{|c|}{ Zone 10} & \multicolumn{3}{|c|}{ Zone 21} \\
\hline & & $\mathrm{G}$ & ET & $\mathrm{P}$ & $\mathrm{G}$ & ET & $\mathrm{P}$ \\
\hline 5 & 1.42 & 10.10 & 9.17 & 0.93 & & & \\
\hline 6 & 1.51 & 10.20 & 9.96 & 0.24 & 11.20 & 9.59 & 1.61 \\
\hline 7 & 1.55 & 11.78 & 10.68 & 1.11 & 9.70 & 10.47 & -0.77 \\
\hline 8 & 1.55 & 10.83 & 10.54 & 0.29 & 9.80 & 10.33 & -0.53 \\
\hline 9 & 1.49 & 9.65 & 10.23 & -0.58 & 8.59 & 10.06 & -1.48 \\
\hline 10 & 1.37 & 11.56 & 9.31 & 2.25 & 9.83 & 9.44 & 0.39 \\
\hline 11 & 1.23 & 10.81 & 8.13 & 2.68 & 14.41 & 8.17 & 6.25 \\
\hline 12 & 1.12 & 12.34 & 7.32 & 5.01 & 12.00 & 7.56 & 4.44 \\
\hline 13 & 1.06 & 11.72 & 6.93 & 4.79 & 12.58 & 7.03 & 5.55 \\
\hline & Average & 11.00 & & & 11.01 & & \\
\hline
\end{tabular}

* ET/E : After Crop Coefficient and Pan Coefficient (RID, 1990)

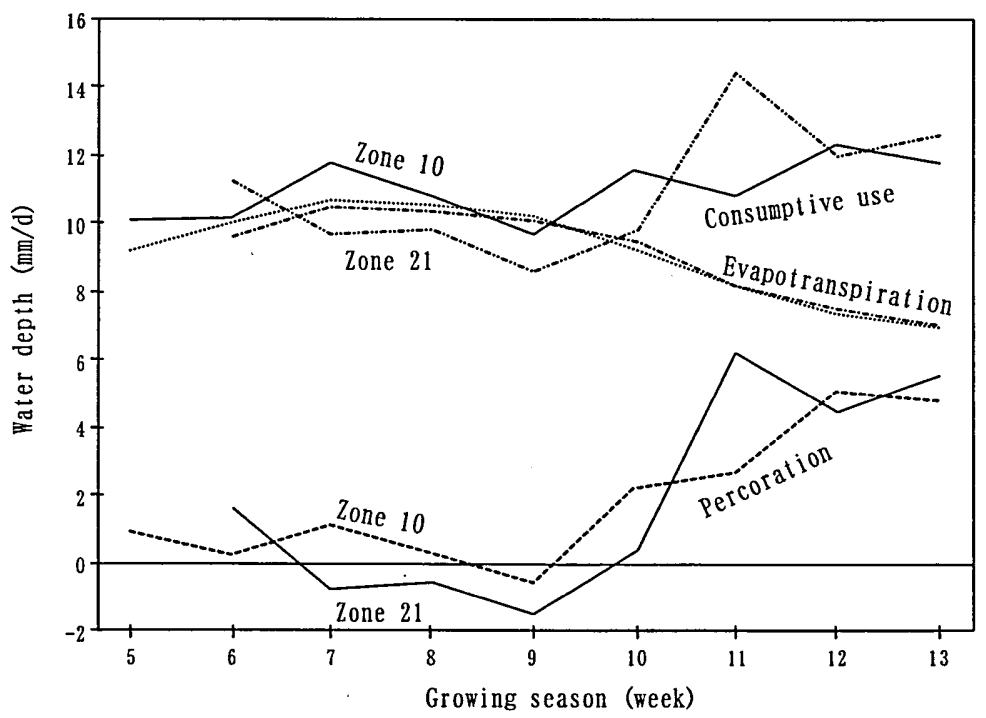

Fig. 4. Consumptive water use and the component

measured value. And, percolation is the value which calculated by deducting evapotranspiration from consumptive water use.

In this district, growing season of the paddy rice is different in the every paddy field, and the paddy field of the harvesting-finished randomly arises in the growing season latter half, and the number gradually increases. Therefore, seepage from the un-harvesting plot to the harvest-finished plot seems to increase. In Table 1 and Fig. 4, percolation 
shows the negative value. It seemed to supply the water by seepage from surrounding plots or near ditch. Though the measurement was not carried out at the initial stage of growing season, the generation of the similar phenomenon with the latter half in the growing season initial stage is anticipated. And, in puddling season, if puddling water is $300 \mathrm{~mm}$, and puddling period is 30 days, consumptive water use is average $10 \mathrm{~mm} / \mathrm{d}$. Therefore, consumptive water use is also $11.0 \mathrm{~mm} / \mathrm{d}$ on both districts of farm land consolidation and non farm land consolidation through whole growing season.

\section{Ponding depth}

Example of measurement result of ponding depth is shown in Fig. 5 and Fig. 6. Fig. 5 is an example in farm land consolidation district (Zone 10). The water intake is optionally carried out in each field, since the each paddy field has contacted irrigation canal. Fig. 6 is an example in non farm land consolidation district (Zone 21).

Water intake time of each field synchronizes, because plot-to-plot irrigation is done. Still, water intake is one time in a week, intermittent irrigation is done in both districts. From these figures, oprating ponding depth (water level as the goal which recovers ponding depth) is supposed $70-80 \mathrm{~mm}$. In the meantime, amount of each irrigation is $11 \mathrm{~mm} \times$ $7=77 \mathrm{~mm}$, when consumptive water use is $11 \mathrm{~mm} / \mathrm{d}$, and irrigation interval is 7 days. Therefore, it is possible to consider that operating ponding depth is the water level of amount of each irrigation equivalent in taking intermittent irrigation into consideration.

And, the highest ponding depth (the levee height) is estimated at about $150 \mathrm{~mm}$ according to Fig. 5 and Fig. 6.

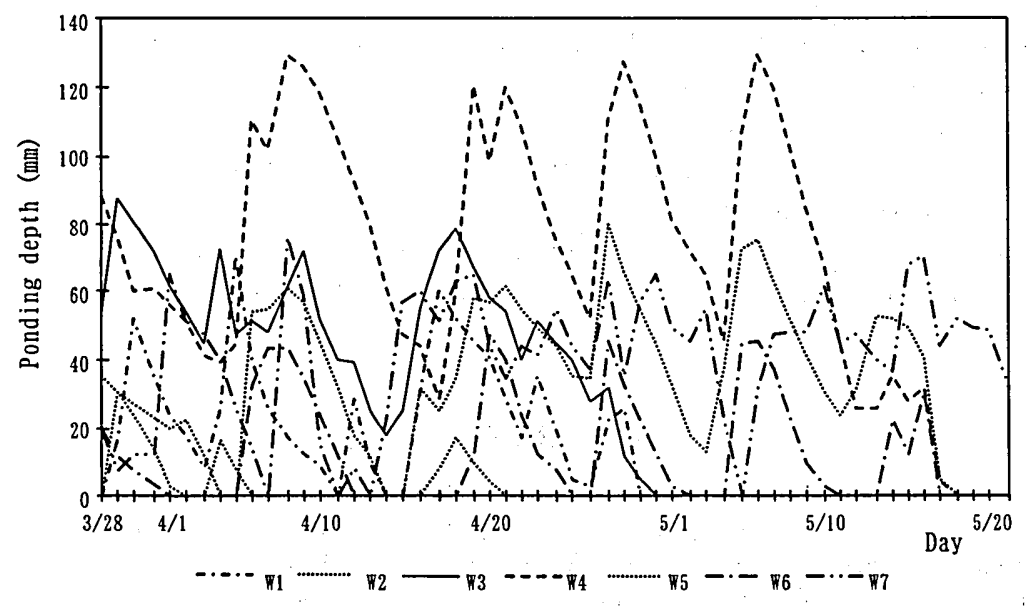

Fig. 5. Example of the observed ponding depth (Zone 10) 


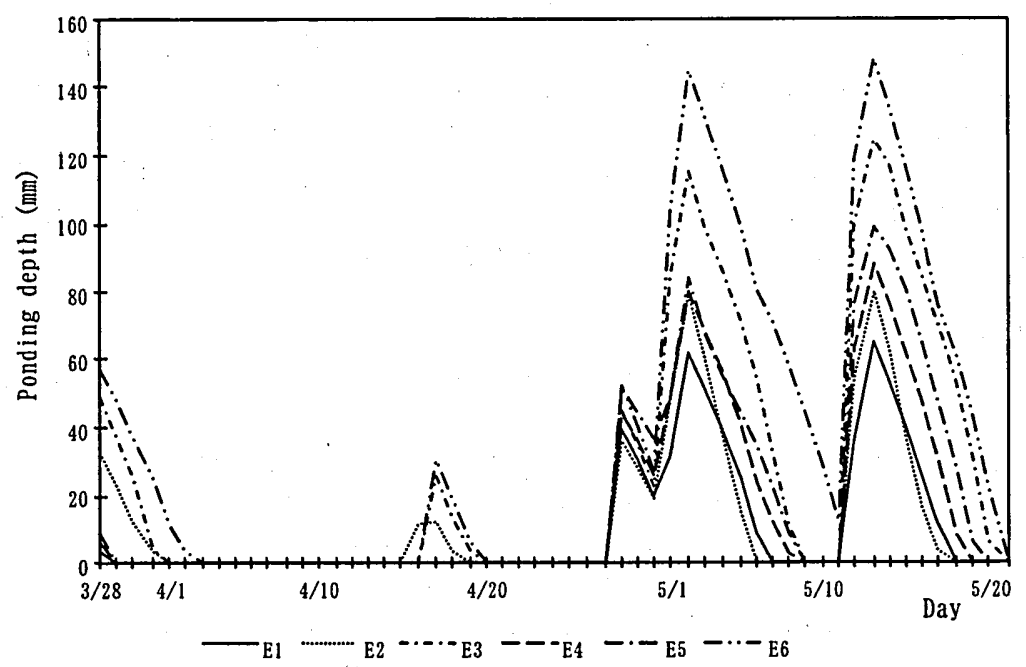

Fig. 6. Example of the observed ponding depth (Zone 21)

\section{CONCLUSION}

Consumptive water use of the paddy field was measured in farm land consolidation district and non farm land consolidation district. And, consumptive water use of the paddy field was $11 \mathrm{~mm} / \mathrm{d}$ regardless of the degree of the farm land consolidation as the result throughout one year.

Operating ponding depth was about $80 \mathrm{~mm}$ from the observation result, and the highest ponding depth was about $150 \mathrm{~mm}$.

These are important basic data in the simulation of the irrigation water calculation: It is expected that the accuracy of future water demand calculation increases, because these basic data were clarified. That these values clarify these dimensions are the important basic dimension in the simulation of the irrigation quantity of water calculation, and the accuracy in which future water demand quantity estimation is high can be expected.

\section{REFERENCES}

Royal Irrigation Department 1990 Crop Coefficient and Pan Coefficient (Thailand)

Testuro Fukuda 2005 Estimation model of water requirement in farmland-Referring to the Thailand gravity irrigation district (1)-,J. Fac. Agr., Kyushu Univ., 50(2) (in press)

Toshisuke Maruyama 1995 New edition irrigation and drainage, Yokendo 